STUDIA I PRACE WYDZIAŁU NAUK EKONOMICZNYCH I ZARZĄDZANIA nr 40, t. 1

\title{
Ewa Bilewicz
}

Uniwersytet Szczeciński

\section{GLOBALNA NIERÓWNOWAGA PO ŚWIATOWYM KRYZYSIE FINANSOWYM W LATACH 2008-2009}

\begin{abstract}
Streszczenie
Celem artykułu jest przedstawienie najważniejszych zmian, jakie zaszły w zjawisku globalnej nierównowagi płatniczej po kryzysie, który miał miejsce w latach 2008-2009. Przeprowadzona analiza wskazuje, że po kryzysie globalna nierównowaga znacząco się zmniejszyła. Jest to efektem między innymi reform strukturalnych podejmowanych przez głównych uczestników tej nierównowagi. Istnieje jednak ryzyko, że w przyszłości globalna nierównowaga może ponownie się zwiększyć, bowiem reformy nie zostały jeszcze zakończone. Obecnie coraz większy udział w procesie narastania globalnej nierównowagi ma nadwyżka na rachunku obrotów bieżących Niemiec.
\end{abstract}

Słowa kluczowe: globalna nierównowaga, nadwyżka obrotów bieżących Niemiec, korekta globalnej nierównowagi płatniczej

\section{Wprowadzenie}

W ostatniej dekadzie jednym z kluczowych problemów gospodarki światowej stała się globalna nierównowaga płatnicza. Uwaga ekonomistów i polityków skupiała się na szybko pogłębiającym się deficycie obrotów bieżących w Stanach

\footnotetext{
*Adres e-mail: bilewicz@wneiz.pl.
} 
Zjednoczonych z jednej strony, a z drugiej na rosnącej nadwyżce, głównie w krajach azjatyckich i naftowych.

Prowadzono debaty dotyczące tego, kto jest głównym sprawcą nierównowagi, jakie będą jej skutki i kto powinien wziąć na siebie zasadniczy ciężar dostosowań w procesie jej zmniejszania - czy kraje nadwyżkowe, mające nadmiar oszczędności w stosunku do wydatków, czy też kraje deficytowe, które cechuje niska stopa oszczędności.

Przed kryzysem oś dyskusji dotyczącej problemu globalnej nierównowagi leżała głównie na linii Stany Zjednoczone - Chiny. Przybrała wręcz postać konfliktu interesów pomiędzy obu państwami. USA stały się głównym krytykiem polityki walutowej Chin ${ }^{1}$. Ich zdaniem zaniżony kurs yuana wobec dolara, który sprzyjał konkurencyjności chińskiego eksportu, miał negatywne następstwa dla gospodarki światowej.

Po globalnym kryzysie finansowym nierównowaga płatnicza zmniejszyła się na skutek zarówno zmian cyklicznych, jak i przeprowadzonych reform. Niektórzy ekonomiści przestrzegają jednak, że w przyszłości może się ponownie pogłębić, co wynika z przekonania, że zasadniczą rolę w procesie zmniejszania nierównowagi odegrało zmniejszenie obrotów handlowych w okresie dekoniunktury. Zmienił się również geograficzny rozkład tej nierównowagi - obecnie w coraz mniejszym stopniu do istnienia globalnej nierównowagi po stronie nadwyżkowej przyczyniają się Chiny, zaś coraz większy udział w tym zjawisku mają Niemcy.

Celem artykułu jest charakterystyka zmian, jakie zaszły w zjawisku globalnej nierównowagi płatniczej po światowym kryzysie finansowym w latach 2008-2009. W pierwszej części artykułu przedstawiono skalę globalnej nierównowagi przed kryzysem i po kryzysie finansowym. W drugiej omówiono niektóre zmiany strukturalne w gospodarkach głównych uczestników tego zjawiska od czasu kryzysu, które przyczyniły się do zmniejszenia globalnej nierównowagi płatniczej. W trzeciej części wskazano przyczyny rosnącej nadwyżki na rachunku obrotów bieżących Niemiec.

\footnotetext{
${ }^{1}$ Por. T. McKinley, Will Pinning the Blame on China Help Correct Global Imbalances?, „CDPR Policy Brief", June 2009, No. 2, s. 1.
} 


\section{Skala nierównowagi po światowym kryzysie finansowym w latach 2008-2009}

W pierwszej dekadzie XXI wieku w Stanach Zjednoczonych niskie oszczędności oraz rosnąca konsumpcja przekładały się na szybko rosnący import, który spowodował ogromny deficyt na rachunku obrotów bieżących tego kraju (rysunek 1). W 2006 roku wyniósł on około 800 mld dolarów (tj. 6\%PKB). Deficyt Stanów Zjednoczonych miał swój odpowiednik w postaci nadwyżek w innych państwach. W krajach naftowych rosnące ceny ropy naftowej spowodowały nadwyżkę w obrotach bieżących, która w 2008 roku wyniosła 332 mld USD. Również w Chinach od początku obecnego stulecia dynamicznie rosła nadwyżka płatnicza, a kraj ten zaczął odgrywać główną rolę w finansowaniu deficytu USA. Niektórzy ekonomiści wskazywali wówczas nadwyżkę tego kraju jako główną przyczynę globalnej nierównowagi płatniczej².

Rysunek 1. Saldo obrotów bieżących dla wybranych krajów w latach 2000-2015 (mld USD)

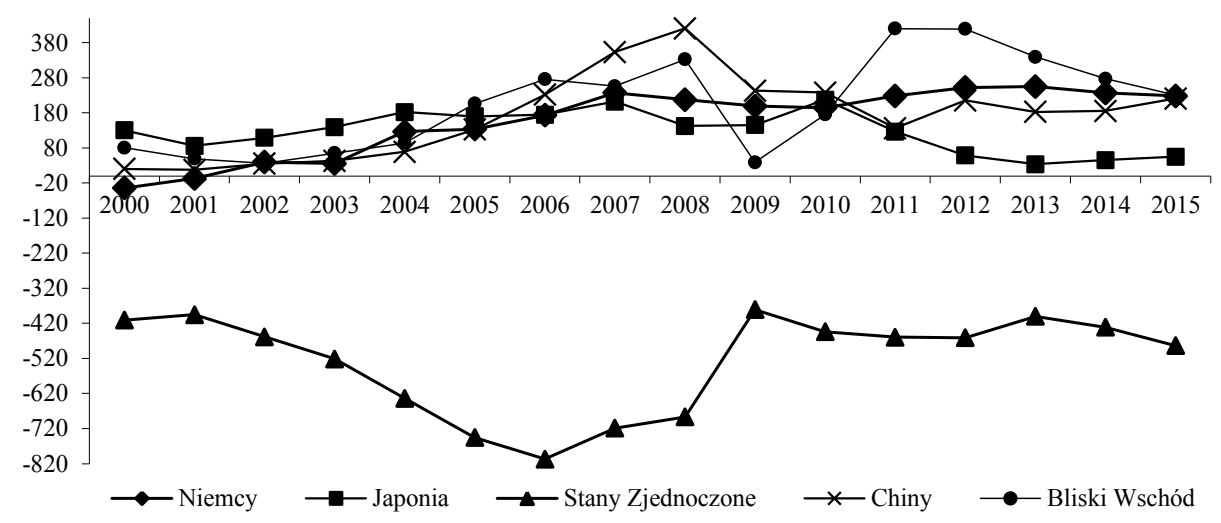

Źródło: World Economic Outlook Database, October 2014, www.imf.org (dostęp 10.11. 2014).

Ponadto od początku obecnego stulecia miał miejsce szybki wzrost dodatniego salda Niemiec. Choć nierównowaga płatnicza tego kraju osiągała rozmiary zbliżone

${ }^{2}$ B. Bernanke, Global Imbalances: Recent Developments and Prospects, Speech at the Bundesbank Lecture, Berlin, Germany, September 2007, www.federalreserve.gov/newsevents/speech/bernanke20110218a.htm (dostęp 15.09.2014). 
do nadwyżki Chin, to nie była ona wówczas przedmiotem tak zdecydowanej krytyki, jak w przypadku tego drugiego kraju, ponieważ strefa euro jako całość miała zrównoważone saldo w obrotach bieżących, a zatem nie miała znaczącego udziału w procesie pogłębiania globalnej nierównowagi płatniczej.

Po wybuchu światowego kryzysu finansowego globalna nierównowaga znacząco się zmniejszyła. Deficyt Stanów Zjednoczonych obniżył się z 687 mld USD w 2008 roku do 400 mld w 2013 roku (2,4\% PKB). Natomiast w Chinach nastąpiła bardzo duża redukcja dodatniego salda. W 2013 roku było ono o ponad połowę niższe niż w 2008 roku. W krajach naftowych nadwyżka gwałtownie się skurczyła w 2009 roku, powiększając się ponownie w kolejnych latach, choć jej poziom ulegał sporym wahaniom (co było uzależnione od kształtowania się cen ropy naftowej). W czasie kryzysu dodatnie saldo Niemiec nieznacznie się obniżyło, jednak w 2011 roku tendencja spadkowa została zahamowana i już w 2012 roku było ono wyższe niż przed kryzysem. Obecnie nadwyżka Niemiec w relacji do PKB jest przeszło trzykrotnie większa niż nadwyżka Chin. W związku z tym obecnie uwaga ekonomistów i polityków w większym stopniu powinna koncentrować się na rosnącym dodatnim saldzie Niemiec, które ma coraz większy wkład w zjawisko globalnej nierównowagi.

\section{Rola Chin i Stanów Zjednoczonych w przywracaniu równowagi płatniczej w gospodarce światowej}

Ograniczenia globalnej nierównowagi po kryzysie było spowodowane zmianami zarówno o charakterze cyklicznym, jak i strukturalnym, jakie miały miejsce w gospodarkach dotychczasowych głównych uczestników globalnej nierównowagi, to jest Chin i Stanów Zjednoczonych ${ }^{3}$. Chiny dostrzegły zagrożenia, jakie niosło ze sobą nadmierne uzależnienie wzrostu gospodarczego od popytu zagranicznego, oraz ryzyko towarzyszące nadmiernej akumulacji rezerw w dolarach amerykańskich. Dotychczasowe oparcie strategii wzrostu gospodarczego na eksporcie przyniosło wiele korzyści krajom azjatyckim. Jednak problemy gospodarcze, które dotknęły ten region na skutek globalnego kryzysu finansowego, pokazały słabość przyjętej strategii. Spowodowała ona bowiem wysokie uzależnienie wzrostu gospodarczego

\footnotetext{
3 World Economic Situation and Prospects 2014, United Nations, New York 2014, s. 18.
} 
krajów azjatyckich od popytu na rynkach globalnych oraz przyczyniła się do narastania nierównowagi zewnętrznej w postaci nadwyżki w obrotach bieżących bilansu płatniczego, co stało się jedną z przyczyn powiększającej się globalnej nierównowagi płatniczej. Stąd też konieczne stało się zwiększenie roli popytu krajowego we wzroście gospodarczym Chin. Wymaga to jednak ograniczenia skłonności podmiotów prywatnych do oszczędzania, która utrudnia wzrost konsumpcji. Zwiększenie popytu wewnętrznego w krajach azjatyckich będzie procesem zapewne trudnym i długotrwałym. Konsumpcja prywatna w Chinach stanowi około 35\% PKB, podczas gdy średnio w krajach rozwiniętych jest to około 60\% PKB. W dyskusji na temat pobudzania chińskiego społeczeństwa do konsumpcji powszechnie wyrażany jest pogląd, że wymaga to przede wszystkim stworzenia powszechnego systemu zabezpieczeń społecznych, dzięki czemu gospodarstwa domowe w tym kraju będą mniej oszczędzać, by móc korzystać ze służby zdrowia, edukacji czy też zabezpieczyć swoje wydatki na emeryturze ${ }^{4}$.

W związku z powyższym chiński rząd podjął reformy mające na celu transformację dotychczasowego modelu rozwoju i zwiększenie konsumpcji mieszkańców Chin. W XII Planie Pięcioletnim obowiązującym w latach 2011-2015 rząd jako priorytet wskazał poprawę warunków życia społeczeństwa. W tym celu zobowiązał się wzmocnić i poszerzyć system zabezpieczeń społecznych, a zwłaszcza włączyć do niego osoby, które dotychczas nie były nim objęte, tj. mieszkańców terenów wiejskich, imigrantów oraz studentów. W dalszym ciągu jednak wydatki na system ubezpieczeń społecznych w Chinach w relacji do PKB są niższe niż średnia dla wszystkich krajów rozwijających się ${ }^{5}$. Rząd zobowiązał się również, że do 2016 roku wybuduje $36 \mathrm{mln}$ mieszkań dla rodzin o niskich dochodach ${ }^{6}$. Ponadto zapowiedział, że mechanizm rynkowy będzie odgrywał większą rolę w ustalaniu cen środków produkcji, a subsydia dla przedsiębiorstw będą stopniowo ograniczane. W rezultacie w Chinach ostatnio wzrosły ceny gazu oraz zlikwidowano preferencyjne taryfy dla energii elektrycznej dla firm o dużym zapotrzebowaniu. Wydaje się jednak, że

${ }^{4}$ M. Asher, The Global Economic Crisis: An Opportunity for Strengthening Asia's Social Protection System?, „ADBI Working Paper Series” 2010, No. 198, s. 7.

${ }^{5}$ H. Ito, U. Volz, The People's Republic of China and Global Imbalances from a View of Sectorial Reforms, „ADBI Working Paper” 2012, No. 393, s. 10.

${ }^{6}$ A. Ahuja, N. Chalk, M. Nabar, P.N'Diaye, N. Porter, An End to China's Imbalances?, „IMF Working Paper" 2012, No. 100, s. 11. 
jak dotąd podejmowane przez rząd reformy nie spowodowały zasadniczych zmian w skłonności do oszczędzania zarówno na poziomie gospodarstw domowych, jak i przedsiębiorstw? ${ }^{7}$ Innym rodzajem działań dostosowawczych, które mają służyć zrównoważeniu wzrostu i redukcji globalnej nierównowagi, jest aprecjacja yuana. W ostatnich latach Chiny dopuściły do szybszego tempa aprecjacji własnej waluty, co przyczyniło się do spowolnienia wzrostu gospodarczego oraz zmiany jego struktury w kierunku większego znaczenia popytu krajowego niż eksportu w tworzeniu PKB.

Po kryzysie zaszły przekształcenia również w bilansie oszczędności i inwestycji Stanów Zjednoczonych. Tendencja spadkowa oszczędności została zahamowana. Wzrost oszczędności w gospodarce amerykańskiej od momentu wybuchu kryzysu został spowodowany zarówno rosnącymi oszczędnościami prywatnymi, jak i rządowymi (rysunek 2).

Rysunek 2. Oszczędności w USA według sektorów instytucjonalnych w latach $2000-2013$ (\% PKB)

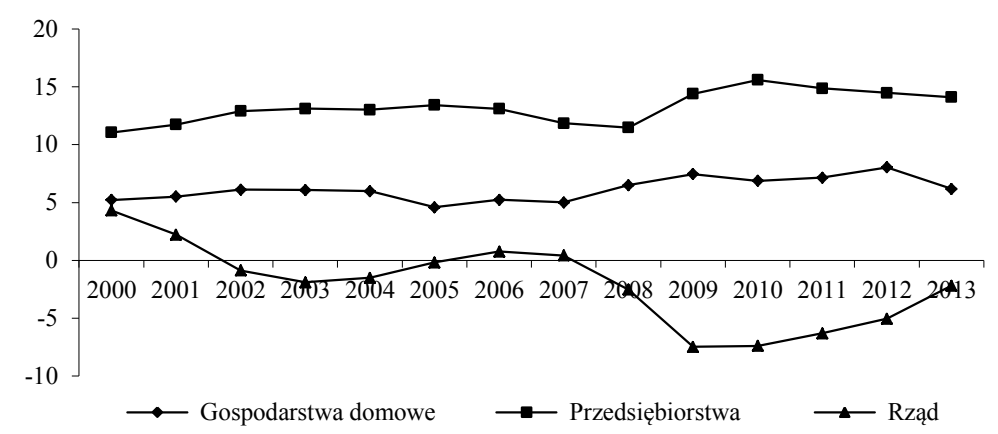

Źródło: www.bea.gov (dostęp 20.11. 2014).

Gospodarstwa domowe ograniczyły swoją skłonność do konsumpcji ze względu na niepewną sytuację ekonomiczną, obawy o zatrudnienie oraz konieczność spłaty wyżej oprocentowanych kredytów hipotecznych. Z kolei oszczędności rządowe, po gwałtownym spadku w latach 2008-2009 spowodowanym uruchomieniem pakietu stymulacyjnego $\mathrm{w}$ celu ratowania zagrożonych upadłością przedsiębiorstw i banków w czasie kryzysu, od 2010 roku zaczęły się zwiększać. Wynikało to przede

\footnotetext{
${ }^{7}$ Ibidem, s. 13.
} 
wszystkim z: wygasania ulg podatkowych i wydatków w ramach „Programu działań antykryzysowych na rzecz pobudzenia gospodarki” (ARRA) wprowadzonego przez Kongres Stanów Zjednoczonych w lutym 2009 roku, aktu prawnego „Budget Control Act" z 2011 roku, na mocy którego Kongres zobowiązał się do redukcji długu o 2,4 bln USD w ciągu 10 lat oraz zwiększenia wpływów do budżetu w wyniku ożywienia gospodarczego ${ }^{8}$.

Pomimo obniżenia globalnej nierównowagi od czasu kryzysu finansowego, na skutek między innymi przedstawionych zmian strukturalnym w gospodarkach Chin i Stanów Zjednoczonych, nadal istnieje ryzyko, że w najbliższych latach będzie się ona pogłębiać, ponieważ czynniki generujące nierównowagę nie zostały jeszcze skorygowane w sposób trwały, a ponadto pojawiło się obecnie nowe źródło globalnej nierównowagi płatniczej, a mianowicie rosnąca nadwyżka Niemiec.

\section{Przyczyny wysokich nadwyżek na rachunku obrotów bieżących Niemiec w ostatniej dekadzie i ich konsekwencje}

Wśród powodów rosnącej nadwyżki na rachunku obrotów bieżących Niemiec analitycy MFW wymieniają między innymi: wysoką konkurencyjność gospodarki niemieckiej opartą na korzystnej specjalizacji i długim okresie umiarkowanego wzrostu płac, rosnące oszczędności gospodarstw domowych, niskie inwestycje odzwierciedlające koniec wcześniejszego bumu budowlanego po zjednoczeniu Niemiec i niepewność związaną z sytuacją ekonomiczną w przyszłości, a także niski wzrost wydajności w sektorze dóbr niehandlowych, który przyczyniał się do spadku inwestycji i konsumpcji .

Gospodarkę niemiecką w ostatnich latach cechował wolniejszy wzrost płac niż w pozostałych krajach strefy euro ${ }^{10}$. Było to skutkiem przeprowadzonych w latach 2003-2005 przez rząd G. Schrödera reform systemu socjalnego i rynku pracy, znanych pod nazwą Agenda 2010. Przy braku możliwości korygowania kursu własnej

${ }^{8}$ Szerzej na ten temat zob. Economic Report of the President, United States Government Printing Office, Washington 2013, www.whitehouse.gov/administration/eop/cea/economic-report-of-the-President/2013, s. 93 (dostęp 9.10.2014).

9 Imbalances and Growth, Update of Staff Sustainability Assessments for G-20 MAP, IMF, September 2013, www.imf.org/external/np/g20/pdf/map2013/map2013.pdf (dostęp 25.10.2014).

${ }^{10}$ G. Ma, R. McCauley, Global and Euro Imbalances: China and Germany, „BIS Working Paper” 2013, No. 424, s. 5. 
waluty przez poszczególne państwa w strefie euro redukcja płac (czyli dewaluacja wewnętrzna) stała się zasadniczym czynnikiem determinującym konkurencyjność krajów strefy euro. Niskie tempo wzrostu płac połączone z szybko rosnącą wydajnością pracy wzmacniało konkurencyjność cenową niemieckich przedsiębiorstw i umożliwiało realizację strategii proeksportowej. Eksport w ostatnich latach, podobnie jak w Chinach, stał się głównym motorem wzrostu gospodarki niemieckiej. Udział eksportu w PKB zwiększył się z 38,5\% w 2004 roku do 50\% w 2011 roku $^{11}$. Efektem były ogromne nadwyżki obrotów bieżących, które inwestowano za granicą, co powodowało poprawę dodatniej międzynarodowej pozycji inwestycyjnej netto.

Relatywnie malejący poziom płac miał również wpływ na krajową absorbcję, bowiem ograniczał wzrost konsumpcji i zwiększał stopę oszczędności gospodarstw domowych. Od 1999 do 2008 roku roczny realny przyrost konsumpcji był niższy niż $\mathrm{w}$ innych krajach strefy euro i rzadko przekraczał $1 \%{ }^{12}$. Zmuszało to niemieckich producentów do poszukiwania zagranicznych rynków zbytu. Wyższe oszczędności gospodarstw domowych nie prowadziłyby do wzrostu nadwyżki na rachunku obrotów bieżących, gdyby zostały wykorzystane do sfinansowania wyższych inwestycji. Jednak w latach 2001-2008 stopa inwestycji w Niemczech pozostawała niższa średnio o około 2-3 pkt procentowe niż w strefie euro i Stanach Zjednoczonych, co wynikało w głównej mierze z niższych niż w pozostałych krajach strefy euro nakładów brutto w sektorze budowlanym ${ }^{13}$.

Niektórzy autorzy uważają, że szybki wzrost nadwyżki na rachunku obrotów bieżących Niemiec zbiegł się z momentem utworzenia unii monetarnej. D. Gros i T. Mayer wskazują, że przed utworzeniem strefy euro ten kraj miał trudności z wykorzystaniem nadwyżki w obrotach bieżących powyżej 4\% PKB. Ponieważ niemieckie banki nie mogłyby inwestować tak dużych nadwyżek handlowych za granicą (zajmować tak dużej długiej pozycji walutowej) ze względu na ryzyko walutowe, marka niemiecka byłaby okresowo rewaluowana, co oddziaływałoby negatywnie na konkurencyjność niemieckiego eksportu. Dzięki wspólnej walucie niemieckie nadwyżki na rachunku obrotów bieżących mogą być inwestowane w innych krajach

11 World Economic Outlook Database, October 2014, www.imf.org (dostęp 10.11. 2014).

12 S. Płóciennik, Skuteczny ale trudny. Czy niemiecki model może być wzorem dla Europy?, EFNI, Raport specjalny, 2013, s. 3.

13 Raport o inflacji, NBP, listopad 2014, s. 11. 
strefy euro, bez konieczności ponoszenia dodatkowego ryzyka walutowego przez banki czy inwestorów instytucjonalnych ${ }^{14}$.

Ponieważ w skali globalnej nadwyżkom na rachunku obrotów bieżących jednych państw towarzyszą deficyty innych krajów, to w związku z tym nadwyżkom niemieckim odpowiadają deficyty innych państw, głównie peryferyjnych krajów strefy euro. Dzięki wspólnej walucie i wspólnej polityce monetarnej kraje te mogły tanio zaciągać kredyty, które finansowały między innymi import z Niemiec. To przyczyniło się do obecnych problemów gospodarczych krajów Europy Południowej. Stąd też polityka proeksportowa Niemiec i będąca jej efektem nadwyżka handlowa jest coraz częściej krytykowana przez inne kraje.

W 2013 roku Departament Skarbu USA w cyklicznej publikacji „Report to Congress on International Economic and Exchange Rate Policies", która jeszcze do niedawna była podstawowym narzędziem krytykowania Chin za niedowartościowany kurs walutowy, wskazał niemieckie nadwyżki handlowe jako jedną z przyczyn spowolnienia wzrostu gospodarczego w strefie euro ${ }^{15}$.

Swoje zastrzeżenia do polityki gospodarczej Niemiec wyraziła również Komisja Europejska, która uznała nadwyżkę na rachunku obrotów bieżących tego kraju za nierównowagę makroekonomiczną ${ }^{16}$. Niemcy nie chcą uznać tych argumentów i twierdzą, że nadwyżki eksportowe są efektem przeprowadzonych reform i świadczą o konkurencyjności niemieckiej gospodarki, jednak pod naciskiem innych państw w ostatnim okresie następuje powolna jej reorientacja w stronę rynku wewnętrznego.

\section{Podsumowanie}

Zmniejszenie globalnej nierównowagi od czasu kryzysu finansowego wynikało w pewnym stopniu ze zmian cyklicznych, to jest ze spadku popytu w krajach mających deficyt na rachunku obrotów bieżących. Do ograniczenia skali globalnej

\footnotetext{
${ }^{14}$ D. Gros, T. Mayer, A Sovereign Welth Fund to Lift Germany's Curse of Excess Savings, „CEPS Policy Brief” 2012, No. 280, s. 1.

${ }^{15}$ Report to Congress on International Economic and Exchange Rate Policies, US Department of the Treasury Office of International Affairs, October 2013, s. 25.

${ }^{16}$ Macroeconomic Imbalances: Germany 2014, Komisja Europejska, „European Economy. Occasional Papers" 2014, No. 174,.
} 
nierównowagi przyczyniły się również przeprowadzone reformy strukturalne w krajach będących głównymi uczestnikami globalnej nierównowagi, które w sposób bardziej trwały skorygowały jej przyczyny.

Pomimo że globalna nierównowaga w ostatnich latach znacząco się obniżyła, nadal powinno podejmować się skoordynowane wysiłki na forum międzynarodowym, by zapobiec pogłębieniu się nierównowagi ponownie w przyszłości. W działania te powinny bardziej zaangażować się Niemcy, bowiem obecnie ten kraj ma coraz większy udział w zjawisku globalnej nierównowagi. Gospodarka niemiecka, podobnie jak chińska, jest nadmiernie uzależniona od sytuacji za granicą. Stąd też coraz więcej państw zgłasza zastrzeżenia do polityki gospodarczej Niemiec, której ubocznym skutkiem jest nierównowaga $w$ innych krajach, zwłaszcza krajach peryferyjnych strefy euro. Zredukowanie niemieckiej nadwyżki na rachunku obrotów bieżących byłoby korzystne dla nich samych, ułatwiłoby też wyjście z kryzysu pozostałym krajom strefy euro.

\section{Literatura}

Ahuja A, Chalk N., Nabar M., N'Diaye P., Porter N., An End to China's Imbalances?, „IMF Working Paper" 2012, No. 100.

Asher M., The Global Economic Crisis: An Opportunity for Strengthening Asia's Social Protection System?, „ADBI Working Paper Series” 2010, No. 198.

Bernanke B., Global Imbalances: Recent Developments and Prospects, Speech at the Bundesbank Lecture, Berlin, Germany, September, 2007, www.federalreserve.gov/ newsevents/speech/bernanke20110218a.htm (dostęp 15.09.2014).

Economic Report of the President, United States Government Printing Office, Washington 2013, www.whitehouse.gov/administration/eop/cea/economic-report-of-the-President/ 2013 (dostęp 9.10.2014).

Gros D., Mayer T., A Sovereign Welth Fund to Lift Germany's Curse of Excess Savings, CEPS, „Policy Brief” 2012, No. 280.

Imbalances and Growth, Update of Staff Sustainability Assessments for G-20 MAP, IMF, September 2013, www.imf.org/external/np/g20/pdf/map2013/map2013.pdf (dostęp 25.10.2014).

Ito H., Volz U., The People's Republic of China and Global Imbalances from a View of Sectorial Reforms, „ADBI Working Paper” 2012, No. 393.

Ma G., McCauley R., Global and Euro Imbalances: China and Germany, BIS „Working Paper" 2013, No. 424. 
Macroeconomic Imbalances: Germany 2014, Komisja Europejska, „European Economy. Occasional Papers" 2014, No. 174.

McKinley T., Will Pinning the Blame on China Help Correct Global Imbalances?, CDPR, „Policy Brief”, June 2009, No. 2.

Płóciennik S., Skuteczny ale trudny. Czy niemiecki model może być wzorem dla Europy?,

EFNI, Raport specjalny, 2013.

Raport o inflacji, NBP, listopad 2014.

Report to Congress on International Economic and Exchange Rate Policies, US Department of the Treasury Office of International Affairs, October 2013.

World Economic Situation and Prospects 2014, United Nations, New York 2014.

\title{
GLOBAL IMBALANCES AFTER 2008-2009 FINANCIAL CRISIS
}

\begin{abstract}
The article presents main changes in the phenomenon of global imbalances after 2008-2009 financial crisis. Research conclusions show that after a crisis global imbalances declined. Some of adjustment reflects structural changes in the economies of main participants of global imbalances. But a risk exists, that in the future global imbalances will widen again because structural changes are not finished yet. Morover, Germany's current account surplus represents an increasingly large share of the global imbalances.

Translated by Ewa Bilewicz

Keywords: global imbalances, Germany's current account surplus, adjustment of global imbalances
\end{abstract}

JEL code: F32 
